\title{
An immunohistochemistry and histopathological study of ankaferd blood stopper in a rat model of cervical inflammation
}

\section{SUMMARY}

OBJECTIVE: Ankaferd Blood Stopper (ABS) is a medicinal plant extract used topically as a hemostatic, anti-inflammatory, and anti-oxidant agent. Its cytoprotective effect mainly depends on its pleiotropic properties by modulating inflammatory mediators such as IL-1 $\beta$, $I L-6$, and TNF- $\alpha$. This study aims to test the possible therapeutic effect of ABS in the treatment of erosive and inflammatory conditions occurring in the uterine cervix.

METHODS: Twenty-four female Wistar Albino rats were used in the present study. Trichloracetic acid was applied intravaginally to establish an experimental rat model of cervicitis. The rats were randomly divided into three groups: group I (injury), group II (injury+isotoinc saline), and group III (injury+ABS). After 3 estrous cycles of ABS and isotonic saline treatment, the amount of inflammation, vascular congestion and erosion were evaluated in the cervical tissues by using a modified semi-quantitative scale of 0-3. Immunohistochemical staining with monoclonal antibodies against IL-13 was also performed.

RESULTS: Compared with group I and II, the ABS group showed the least inflammatory cell infiltration, vascular congestion and cervical erosion, compared with the ABS group prominent IL-13 staining observed in group I and group II.

CONCLUSION: Our data suggest that ABS is a highly effective alternative to induce normal cervical epithelium and can be used safely in the treatment of cervical inflammation with or without cervical erosion.

KEYWORDS: Uterine cervicitis. Uterine cervical diseases. Inflammation. Interleukin-1beta. Plant extracts/*pharmacology.

\section{INTRODUCTION}

Cervicitis, which is characterized by the inflammation of the cervical mucosa, is commonly provoked by distinct etiologic factors including sexual infections, hormonal alterations, irrational use of contraceptive devices and trauma to the cervix. ${ }^{1}$ Clinical significance of the condition concerning evaluation, monitoring, and treatment usually depends on the stage of disease as either being acute or chronic rather than histologic appearance. Although rarely diagnosed during pregnancy, it can cause infection of the membranes and gross malformations of the fetus. ${ }^{2}$ Moreover, in the postpartum period, cervical inflammation can also provoke the development of fetal abnormalities, intrauterine growth restriction, premature birth and perineal pain with infectious complications to the mother. ${ }^{3}$ In this context, the 
appropriate treatment of cervical inflammation in either pregnant or non-pregnant women is paramount for the prevention of further complications associated with an inflammatory reaction within the lower genitourinary tract ${ }^{4}$. Apart from surgical interventions, which are usually preferred in chronic cases, anti-inflammatory and antimicrobial drugs, physiotherapy, immunomodulating agents and drugs that restore the normal biocenosis of the vagina are standard treatment options with variable results. ${ }^{5}$

Ankaferd Blood Stopper (ABS) is a herbal extract that has been reported to have hemostatic, anti-inflammatory, anti-oxidant, anti-infective and wound healing properties. It consists of five distinct plants namely: Thymus vulgaris, Glycyrrhiza glabra, Vitis vinifera, Alpinia officinarum, and Urtica dioica. Although the exact pathophysiology underlying the unique effect of ABS remains an area of active investigation, $A B S$ induces the formation of an encapsulated complex protein web with vital erythroid aggregation which covers the whole physiological hemostatic process (Figure 1) ${ }^{6,7}$ Besides from these hemostatic properties, the anti-inflammatory effect of ABS are reported to be based on the effect of proinflammatory cytokines including tumor necrosis factor- $\alpha$ (TNF- $\alpha$ ), interleukin- 6 (IL-6) and its antioxidant potential. ${ }^{8-10}$

Difficult to cure in nature, inflammation of the cervix can be treated with topical application of ABS based on its anti-inflammatory effect, which was proved in several studies. ${ }^{10,11}$ Unfortunately, to our knowledge, no study in the literature evaluates the beneficial effect of ABS explicitly on inflammatory response during cervicitis. Therefore, in this study, we attempted to define and characterize the possible role of ABS in the elimination of a chronic inflammatory process in a rat model of cervicitis.

\section{MATERIALS AND METHODS}

\section{Materials and experimental design}

The study was approved by the Institutional Animal Use and Care Committee of Canakkale Onsekiz Mart University (COMU) and performed following the Helsinki Declaration of World Medical Association recommendations on animal studies. Wistar albino rats were obtained from COMU Experimental Research Application and Research Center. Twenty-four female Wistar Albino rats were used in the study, with a mean age of four months and a mean weight of 240-300 g. The rats were housed in stainless steel cages in an animal room maintained at a standard humidity (45\%-50\%) and temperature $22 \pm 2^{\circ} \mathrm{C}$ with 12 hour light periods (12 hours of daylight/12 hours of dark). All animals were fed standard food and water and, twelve hours before the study procedure, feeding was stopped, and the rats were only allowed to drink water. The entire experiment was conducted under half-sterile conditions.

\section{Experimental procedure}

Before starting the study, on the basis of experimental models of intrauterine synechia induced by trichloroacetic acid ${ }^{12}$, we tested trichloroacetic acid intravaginally to induce cervical lesion on 2 Wistar Albino rats. To establish the experimental model, 0.2 $\mathrm{ml}$ of trichloroacetic acid was injected intravaginally. After 3 estrous cycles, the animals were sacrificed and confirmed that 1 dose of $0.2 \mathrm{ml}$ intravaginal trichloroacetic acid is sufficient to induce inflammatory cervicitis.

\section{Groups}

After establishing and confirming the experimental model, the study was started with 24 Wistar albino rats. The stage of the estrous cycle for each female rat was determined by histological examination of cells in vaginal smears taken daily at 09 a.m. to 10:00 am. It is known that the rat estrous cycle consists of four stages with a typical cycle every 4 to 5 day. The cycle of the rats was synchronized according to their vaginal smear analysis and divided into three groups.

Group I (injury, $\mathrm{n}=8$ ): after trichloroacetic acid application, rats did not receive any treatment. Rats were further sacrificed after 3 estrous cycles and cervix of the rats were removed for evaluation.

Group II (Isotonic saline group, $\mathrm{n}=8$ ): after 1 day from the trichloroacetic acid application, rats were received $2 \mathrm{ml} /$ day intravaginal isotonic saline for 3 estrous cycles. Rats were further sacrificed after 3 estrous cycles and cervix of the rats were removed for evaluation.

Group III (ABS group, $\mathrm{n}=8$ ): after 1 day from the trichloroacetic acid application, rats received $2 \mathrm{ml} /$ day intravaginal ABS (ABS; İmmun İlaç Kozmetik Ltd, Istanbul, Turkey) for 3 estrous cycles. The dosage of ABS was determined from previous studies. ${ }^{13}$ Rats were further sacrificed after 3 estrous cycles and cervix of the rats were removed for evaluation. 


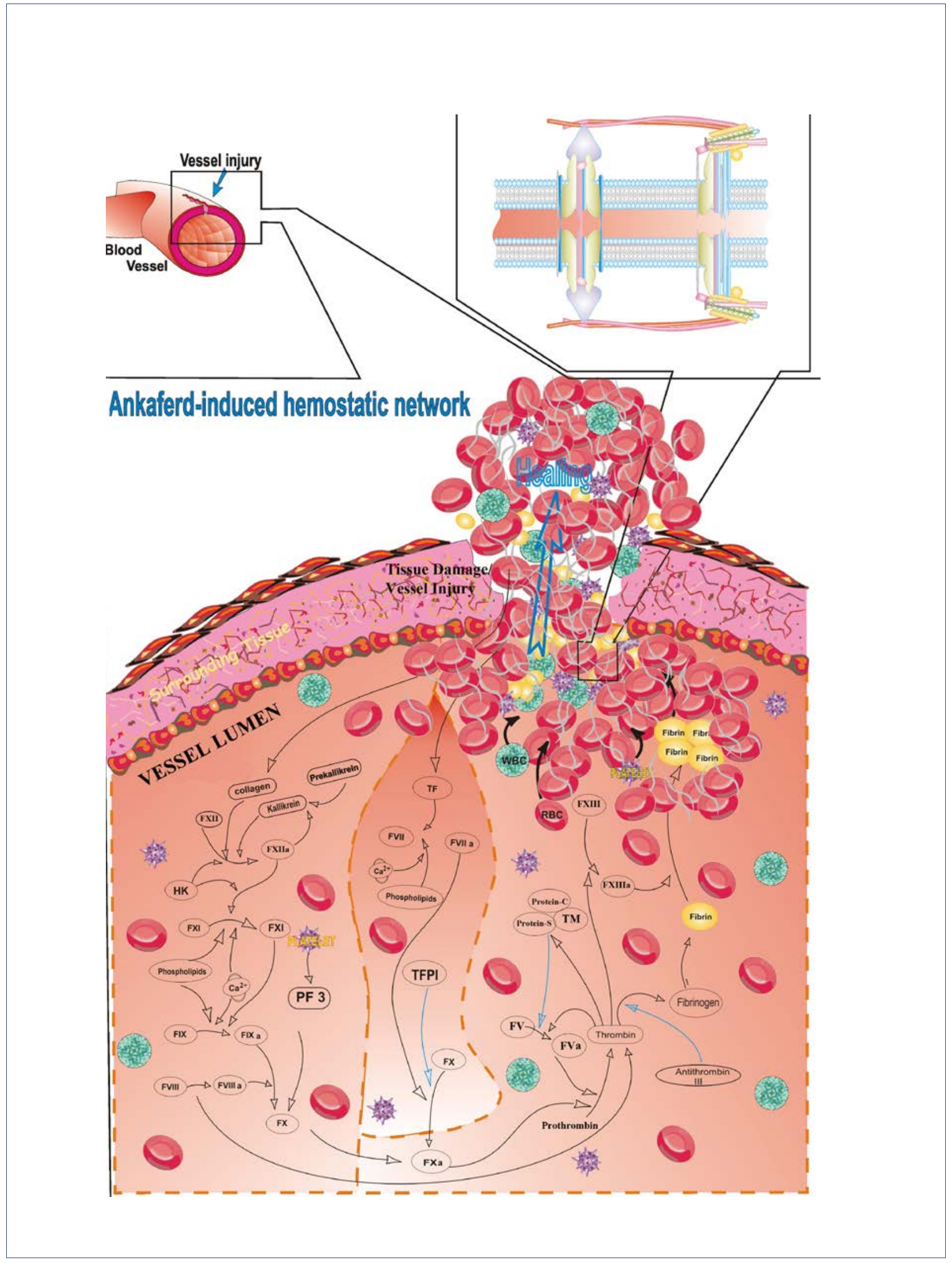

FIGURE 1 The basic mechanism of action for Ankaferd Blood Stopper (ABS) is the formation of an encapsulated protein network that provides focal points for erythrocyte aggregation. ABS-induced formation of the unique protein network within the vital erythroid aggregation covers the entire physiological haemostatic process. Red blood cell (RBC) elements (such as spectrin and ankrin surface receptors, and internal ferrochelatase enzyme), related transcription factors (such as GATA-1) and RBC-related proteins (such as urotensin II) are the main targets of ABS. Source: Modified from Ref. [6] with permission. 


\section{Macroscopic and histopathological examinations}

Macroscopic findings were recorded by one observer who participated in the injection experiments. Groups were compared macroscopically regarding the presence of erythema, edema and small ulcers.

To investigate histopathologic changes, cervical tissue samples were consecutively numbered and placed in 10\% formaldehyde and sent to the histology department of COMU. Evaluation of the pathology specimens was done by a histology specialist who was blind to the three study groups.

After fixation with formaldehyde, cervical tissues were embedded in paraffin. The paraffin blocks were cut in $5 \mathrm{~mm}$ thickness on Rotary Microtome (Leica RM2125 RTS), and the sections were stained with hematoxylin and eosin (H\&E) and Masson's trichrome method. The histopathologic sections were examined under a light microscope (Zeiss AxioScope A1) for the presence of inflammation, congestion (vascular dilation), and erosion and rated on a modified semi-quantitative scale of 0-3 as also stated by Kilic et al. ${ }^{12}$ The amount of inflammation was scored as follows: 0, no inflammation; 1 , presence of occasional plasma cells and lymphocytes; 2 , significant existence of plasma cells, eosinophils and neutrophils; and 3, existence of many inflammatory cells and microabscesses. Vascular congestion was scored as: 0 , no vascular congestion; 1 , mild vascular congestion; 2 , moderate vascular congestion; and 3; intense vascular congestion. Erosion was scored as: 0 , intact epithelium, no erosion; 1 , mild epithelial damage; 2 , full layer epithelial damage, intact lamina proprium; and 3; damage beyond lamina propria, deep layer involvement. The total tissue damage score was calculated by adding up these scores.

\section{Immunohistochemical examination}

Immunohistochemistry for IL-1 $\beta$ was carried out with a commercial kit (Cell Signaling Technology, Danvers, MA) following the manufacturer's protocol. In brief, approximately 4-micron tissue slices were fixed in 10\% neutral-buffered formalin and before proceeding with the staining protocol, slides deparaffinized and rehydrated. Antigen retrieval method was applied to conduct immunohistochemistry on the paraffin sections. Sections were heated in a microwave at 200 watts for 20 minutes in 10mM EDTA and left to cool down at room temperature for $20 \mathrm{~min}$. A PAP pen was used to delineate the tissue sections. Hydrogen peroxide (Thermo Scientific, Erembodegem, Belgium) was dropped to the sections and remained there for 15 minutes. The sections were then washed with phosphate-buffered saline (PBS). Sections that were incubated with primary antibodies were marked with AEC chromogen (ThermoScientific ${ }^{\mathrm{TM}}$ ) and counterstained with Mayer's hematoxylin. Finally, each section was dehydrated and cover-slipped. Immunohistochemical evaluation and scoring were done according to Jiang et al. ${ }^{14}$ According to this scoring, IL-1 $\beta$ immunostaining scores were calculated by initial defining of both the staining intensity ( 0 , no staining; 1 , weak but detectable staining; 2 , moderate; and 3 , strong staining) and the percentage of positively stained cells ( 0 , no staining; 1 , $<25 \%$ staining; $2,>25 \%$ and $<50 \%$ staining; $3,>50 \%$ staining). The final score was measured by multiplying scoring intensity by the percentage of positive stained score.

\section{Statistical analyses}

Statistical analysis was performed using SPSS for Windows 19.0 (Chicago Inc., Chicago, IL). All continuous variables were expressed as the mean \pm standard deviation (SD) and median (minimum-maximum). Because of the small sample size and non-normal distribution of the data non-parametric tests were used to evaluate the results. The mean values were compared by Kruskal-Wallis, and Mann-Whitney U tests. A p-value lower than 0.05 was considered as statistically significant.

\section{RESULTS}

All of the rats in group I, II and III survived during the study period. Macroscopic erythema and edema were observed more prominently in group I and II compared to group III. Small ulcers were only seen in one rat in group I and in two rats in group II. No macroscopic ulcers were found in the cervical mucosa of ABS group.

According to total tissue injury scores, mean injury scores were found to be statistically elevated in group I and group II compared to ABS group. Subgroup analysis revealed that group I and II have increased inflammation $(\mathrm{p}=0.018)$, vascular congestion $(p=0.001)$ and erosion scores $(p>0.001)$ 
TABLE 1: TISSUE INJURY SCORES OF STUDY GROUPS

\begin{tabular}{|c|c|c|c|c|}
\hline & Inflammation & Congestion & Erosion & Total \\
\hline \multicolumn{5}{|l|}{ Group I (n=8) } \\
\hline Mean $( \pm S D)$ & $2.75 \pm 0.46$ & $2.37 \pm 0.51$ & $2.37 \pm 0.74$ & $7.50 \pm 0.92$ \\
\hline Median (min-max) & $3(2-3)$ & $2(2-3)$ & $2(1-3)$ & $7(6-9)$ \\
\hline \multicolumn{5}{|l|}{ Group II $(n=8)$} \\
\hline Mean $( \pm S D)$ & $2.75 \pm 0.46$ & $2.25 \pm 0.71$ & $2.28 \pm 0.71$ & $7.37 \pm 0.91$ \\
\hline Median (min-max) & $3(2-3)$ & $2(1-3)$ & $2(1-3)$ & $7(6-9)$ \\
\hline \multicolumn{5}{|l|}{ Group III (n=8) } \\
\hline Mean $( \pm S D)$ & $1.75 \pm 0.70$ & $1.01 \pm 0.75$ & $0.12 \pm 0.35$ & $2.88 \pm 1.25$ \\
\hline Median (min-max) & $2(0-3)$ & $1(0-2)$ & $0(0-1)$ & $3(1-5)$ \\
\hline p & $0.018 a$ & $0.001 b$ & $<0.001 c$ & $<0.001 d$ \\
\hline
\end{tabular}

a,b,c,d Group III vs Group I and II
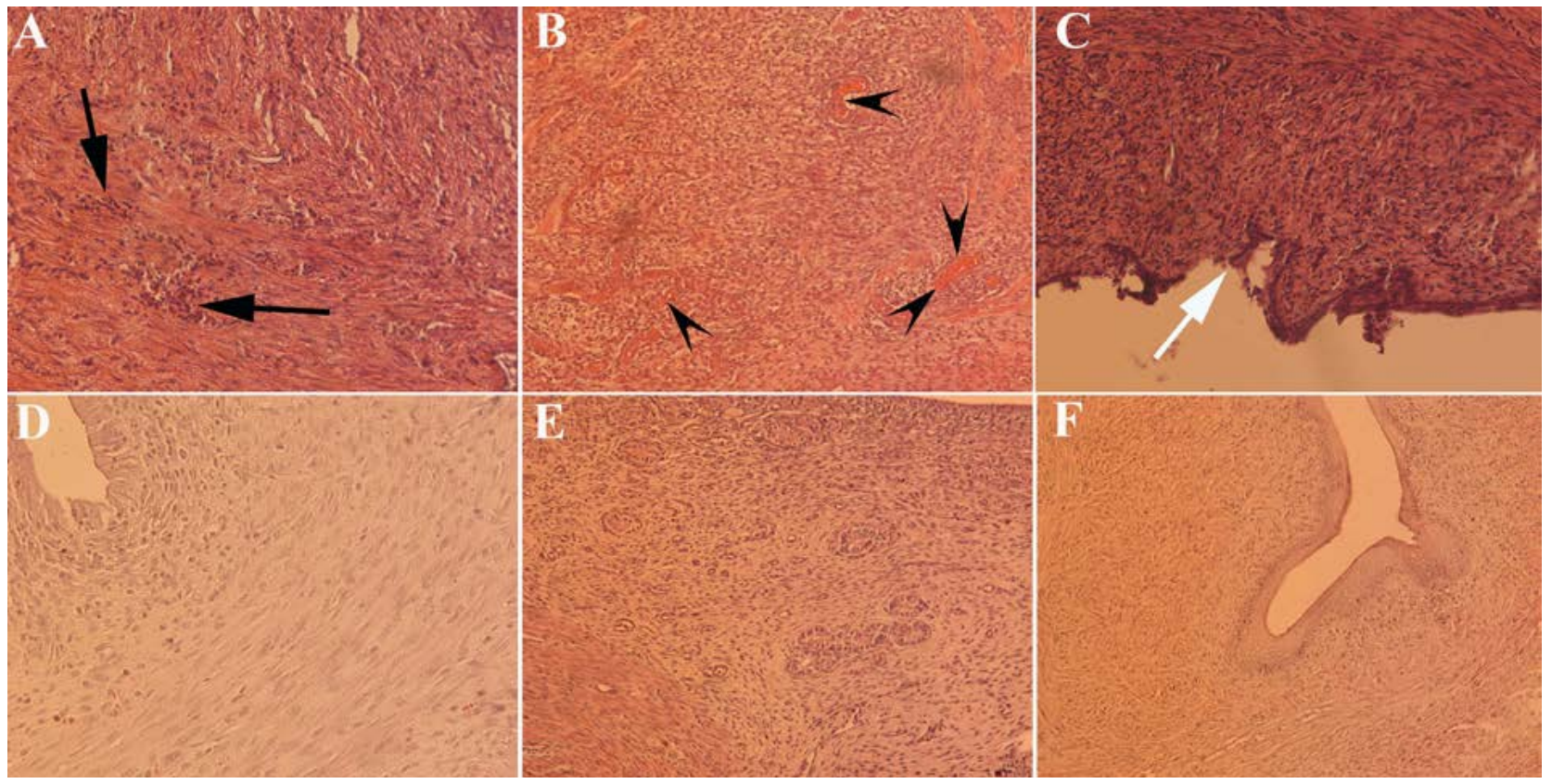

FIGURE 2. Microscopic comparison of inflammation (A,D), vascular congestion ( $B, E$ ) and erosion (C,F) in group II (injury+isotonic saline) and in group III (injury+Ankaferd BloodStopper [ABS]). Histology of isotonica saline treated group is shown in panels $A, B, C$ and histology of $A B S$ treated group is shown in panels $D, E$, F. Isotonic saline treated group showed significantly greater histological damage including increased cellular inflammation (A: black arrow), vascular congestion (B: arrowhead) and erosion (C: white arrow) compared to ABS treated group.

compared to ABS group (Table 1). Mean total injury scores for groups I, II and III were found to be $7.50 \pm 0.92,7.37 \pm 0.91$ and $2.88 \pm 1.25$ respectively. Group III had significantly lower total scores compared with group I and II (p<0.001). Figure 2 shows the microscopic comparison of inflammation, vascular congestion, and erosion in group II and III.

Immunohistochemical analysis revealed that median IL-1 $\beta$ expression scores in group I, II and III were 4 (2-9), 4 (2-9) and 2 (1-4) respectively. IL-1 $\beta$ expression was found to be higher in group I and II compared to group III ( $\mathrm{p}=0.018)$.

\section{DISCUSSION}

The purpose of the present study was to investigate the macroscopic and microscopic changes in the cervical mucosa as well as immunohistochemical staining for IL-1 $\beta$ in response to ABS treatment in a chemically induced cervicitis model of rats. We observed that intravaginal ABS injection compared with isotonic saline results in a significant reduction in the number of inflammatory cells in cervical mucosa. Furthermore, ABS seemed to have significant protective effects on vascular congestion and cervical erosion. 
ABS is a novel hemostatic agent that has pleiotropic and profound effects on the hematologic and immune system including anti-microbial, anti-neoplastic, anti-mutagenic, and antioxidant as well as tissue-healing properties. ${ }^{6,15,16}$ The mechanistic basis of this pleiotropism remains a mystery despite extensive research during the past decade. It has been suggested that the unique action of the ABS mechanism mainly depends on the protein agglutination and polymerization that modulates the erythroid aggregation and vascular endothelium. ${ }^{7}$ In a recent study by Simsek et al. ${ }^{15}$ a detailed proteomic and transcriptomic analyses of ABS was performed in order to explain the pleiotropic effects of this hemostatic agent. Authors demonstrated that hepatocyte nuclear factor-4a, malic enzyme-1, midkine and protein inhibitor of activated signal transducer and activator of transcription (PIAS)-2 are the main components that are responsible from the pleiotropic effects of ABS. Although less studied, ABS has also shown promising results in inflammatory conditions related to cartilage tissue, gastric mucosa, pericardial tissue, and liver., ${ }^{917-19}$ Dynactin, Egr-1, Midkine, NF-1, Twinfilin, V-myc, and Yin Yang 1 can contribute both the anti-inflammatory and tissue-healing effects of ABS with various mechanisms. ${ }^{15}$

This study demonstrated that IL- $1 \beta$ expressions are significantly down-regulated in the ABS group compared with the other two groups. Although our study is the first to investigate the expression of IL$1 \beta$ in ABS treated cervical mucosa, a study by Amanvermez et al. ${ }^{20}$ IL-1 $\beta$ and Interleukin-10 (IL-10) investigated expressions during the fracture healing process with or without ABS application to the bone fracture. IL-1 $\beta$ levels were found to be decreased in the ABS-treated experimental rat group. Being a potent inflammatory cytokine, which is up-regulated during inflammation, IL-1 $\beta$ has a vital role in the host defense and inflammatory response. ${ }^{21}$ However, overproduction or prolonged expression of IL-1 $\beta$ in the inflammatory course may result in enhanced tissue destruction due to the immune cells overactivation and the production of proteases, along with decreased collagen matrix formation and decreased granulation tissue formation..$^{22,23}$ For this reason, ABS could exert its beneficial effects by limiting IL-1 $\beta$ induced vascular permeability, neutrophil recruitment and maturation in the early phases of inflammation.

In addition to the decreased expressions of IL-
$1 \beta$ in the ABS group, we found that cervical erosion was less prominent in the ABS group compared to the other two groups. Cervical mucosal erosion, which is one of the unique features of cervicitis, can be caused by trauma, deep lacerations, infections, and contraceptive devices. ${ }^{24}$ The eroded cervical surface could enlarge, and complaints like excessive discharge can be more prevalent. Although treatment options may vary depending on the acute or chronic nature of the process, there is still a limited approach to cure cervical erosions related to chronic inflammation. In this context, ABS can effectively promote the healing of cervical erosion with no side effects.

After the injection, all the animals survived after 3 estrous cycles indicating that local application of ABS is safe and has no severe side effects. This is important because ABS is still considered a novel antihemostatic and anti-inflammatory agent since the extensive characterization of the pharmacological properties of ABS needs to be carried out. Although no other study in the literature compares the safety and optimal dosage of ABS in cervical inflammation, data from other trials demonstrated that ABS is safe and efficient in distinct disease conditions including dental surgery, wound healing, epistaxis, gastrointestinal bleeding, and peritoneal adhesion..$^{13,16,25-28}$ Unfortunately, because of unknown optimal dosage schedules which can cause premature safety and efficacy studies to fail and may limit further research, it is crucial to conduct preliminary analysis to determine ABS's optimal dosage in cervical inflammation. Therefore, this preliminary study is of paramount importance because it provides important insights into the understanding of the histopathologic and immunohistochemical basis of ABS induced cervical mucosa protection.

One of the limitations of the present study is the lack of immunohistochemical analysis apart from IL-1 $\beta$. Immunohistochemical staining with monoclonal antibodies against pro-inflammatory cytokines and growth factors such as tumor necrosis factor- $\alpha$ (TNF- $\alpha$ ), interleukin-6 (IL-6), transforming growth factor-alpha (TGF-alpha) and epidermal growth factor receptor (EGFR) would be noteworthy to understand the enigmatic role of ABS in the cervical inflammatory process. Another limitation of our study is the relatively short follow-up period of rats which cannot encompass the natural recovery period. 
In conclusion, ABS may be used safely and effectively in cervical inflammatory conditions as a natural remedy.

ABS effectively inhibits the inflammatory process and has a unique role as an effective wound-healing and anti-inflammatory agent. Despite the existence of several pharmacological and herbal options for cervicitis, present work demonstrates that ABS effectively decreases the expression of IL-1 $\beta$ resulting in a decrease of inflammation, vascular congestion, and mucosal erosion. Further studies are required to evaluate the clinical benefits and any possible adverse effects of ABS application on cervical mucosa.

\section{RESUMO}

OBJETIVO: Ankaferd Blood Stopper (ABS) é um extrato de plantas medicinais utilizado topicamente como um agente hemostático, anti-inflamatório e antioxidante. O seu efeito citoproteico depende principalmente das suas propriedades pleiotrópicas por meio da modulação de mediadores inflamatórios tais como IL-1ß, IL-6 e TNF-a. O objetivo deste estudo é testar o possível efeito terapêutico do ABS no tratamento de condições erosivas e inflamatórias que ocorrem no colo uterino.

MÉTODOS: Vinte e quatro ratas Wistar Albino foram utilizadas no presente estudo. O ácido tricloroacético foi aplicado intravaginalmente para estabelecer um modelo experimental de cervicite em ratos. Os ratos foram divididos aleatoriamente em três grupos: grupo I (lesão), grupo II (lesão + fisiológico sérico) e grupo III (lesão + ABS). Após três ciclos estrais de ABS e tratamento fisiológico sérico, as quantidades de inflamação, congestionamento vascular e erosão foram avaliadas nos tecidos cervicais usando uma escala semiquantitativa modificada de 0-3. Coloração imuno-histoquímica com anticorpos monoclonais contra IL-13 também foi realizada.

RESULTADOS: Em comparação com os grupos I e ll, o grupo ABS mostrou menos infiltração de células inflamatórias, congestionamento vascular e erosão cervical. Além disso, em comparação com o grupo ABS, observou-se uma coloração proeminente de IL-13 no grupo I e no grupo II.

CONCLUSÃO: Nossos dados sugerem que o ABS é uma alternativa altamente eficaz para induzir o epitélio cervical normal e pode ser utilizado com segurança no tratamento da inflamação cervical com ou sem erosão cervical.

PALAVRAS-CHAVE: Cervicite uterina. Doenças do colo do útero. Inflamação. Interleucina-1beta. Extratos vegetais/*farmacologia.

\section{REFERENCES}

1. Mattson SK, Polk JP, Nyirjesy P. Chronic cervicitis: presenting features and response to therapy. J Low Genit Tract Dis. 2016;20(3):e30-3.

2. Nugent RP, Hillier SL. Mucopurulent cervicitis as predictor of chlamydial infection and adverse pregnancy outcome. The Investigators of the Johns Hopkins Study of Cervicitis and Adverse Pregnancy Outcome. Sex Transm Dis. 1992;19(4):198-202.

3. Blake RL Jr, Dilger S, Ingram E, Gay JW. Cervical inflammation and preterm delivery in pregnant women with a history of preterm delivery. I Am Board Fam Pract. 1994;7(6):465-71.

4. Marrazzo JM, Martin DH. Management of women with cervicitis. Clin Infect Dis. 2007;44(Suppl 3):S102-10.

5. Taylor SN, Lensing S, Schwebke J, Lillis R, Mena LA, Nelson AL, et al. Prevalence and treatment outcome of cervicitis of unknown etiology. Sex Transm Dis. 2013;40(5):379-85.

6. Beyazit Y, Kurt M, Kekilli M, Goker H, Haznedaroglu IC. Evaluation of hemostatic effects of Ankaferd as alternative medicine. Altern Med Rev. 2010;15(4):329-36.

7. Haznedaroglu BZ, Beyazit Y, Walker SL, Haznedaroglu IC. Pleiotropic cellular, hemostatic, and biological actions of Ankaferd hemostat. Crit Rev Oncol Hematol. 2012;83(1):21-34.

8. Sen V, Uluca U, Ece A, Güneş A, Zeytun H, Arslan S, et al. Role of Ankaferd on bacterial translocation and inflammatory response in an experimental rat model of intestinal obstruction. Int J Clin Exp Med. 2014;7(9):2677-86.

9. Hasgul R, Uysal S, Haltas H, Akyol S, Yuksel Y, Gurel A, et al. Protective effects of Ankaferd blood stopper on aspirin-induced oxidative mucosal damage in a rat model of gastric injury. Toxicol Ind Health. 2014;30(10):888-95
10. Koçak E, Akbal E, Taş A, Köklü S, Karaca G, Can M, et al. Anti-inflammatory efficiency of Ankaferd blood stopper in experimental distal colitis model. Saudi J Gastroenterol. 2013;19(3):126-30.

11. Kilic O, Gonen M, Acar K, Yurdakul T, Avunduk MC, Esen HH, et al. Haemostatic role and histopathological effects of a new haemostatic agent in a rat bladder haemorrhage model: an experimental trial. BJU Int. 2010;105(12):1722-5.

12. Kilic S, Yuksel B, Pinarli F, Albayrak A, Boztok B, Delibasi T. Effect of stem cell application on Asherman syndrome: an experimental rat model. J Assist Reprod Genet. 2014;31(8):975-82.

13. Karaca G, Aydin O, Pehlivanli F, Kocael A, Pekcici R, Duymus E, et al. Effect of Ankaferd blood stopper in experimental peritoneal adhesion model. Ann Surg Treat Res. 2016;90(4):213-7.

14. Jiang JF, Deng Y, Xue W, Zheng TP, Sun AJ. Increased expression of interleukin 37 in the eutopic and ectopic endometrium of patients with ovarian endometriosis. Reprod Sci. 2016;23(2):244-8.

15. Simsek C, Selek S, Koca M, Haznedaroglu IC. Proteomic and transcriptomic analyses to explain the pleiotropic effects of Ankaferd blood stopper. SAGE Open Med. 2017;5:2050312117722569.

16. Uğur A, Saraç N, Çankal DA, Özle M. The antioxidant and antimutagenic activities of Ankaferd blood stopper: a natural hemostatic agent used in dentistry. Turk J Med Sci. 2016;46(3):657-63.

17. Taş A, Köklü S, Beyazit $Y$, Karaca G, Astarcı HM, Akbal E, et al. Percutaneous ankaferd injection to in vivo liver tissue in comparison to ethanol in an experimental rat model. Clin Res Hepatol Gastroenterol. 2011;35(89):549-53. 
18. Nazli Y, Colak N, Alpay MF, Haltas H, Aksoy ON, Akkaya IO, et al. Assessment of the efficacy of Ankaferd blood stopper on the prevention of postoperative pericardial adhesions. Cardiovasc J Afr. 2014;25(3):100-5.

19. Satar NY, Akkoc A, Oktay A, Topal A, Inan K. Evaluation of the hemostatic and histopathological effects of Ankaferd Blood Stopper in experimental liver injury in rats. Blood Coagul Fibrinolysis. 2013;24(5):518-24.

20. Amanvermez R, Gunay M, Piskin A, Keles G, Tomak L. TNF- $\alpha, \mid L-1 \beta$, and oxidative stress during fracture healing with or without ankaferd. Bratisl Lek Listy. 2013;114(11):621-4.

21. Slaats |, Ten Oever J, van de Veerdonk FL, Netea MG. IL-1及/IL-6/CRP and IL-18/ferritin: distinct inflammatory programs in infections. PLoS Pathog. 2016;12(12):e1005973.

22. Rapala K, Laato M, Niinikoski J, Kujari H, Söder O, Mauviel A, et al. Tumor necrosis factor alpha inhibits wound healing in the rat. Eur Surg Res. 1991;23(5-6):261-8

23. Jiang L, Dai Y, Cui F, Pan Y, Zhang H, Xiao J, et al. Expression of cytokines, growth factors and apoptosis-related signal molecules in chronic pressure ulcer wounds healing. Spinal Cord. 2014;52(2):145-51.

24. Zhu T, Chen Z, Xia Q, Jiang S, Jin Q, Farahani MR, et al. A suppository for treating cervical erosion and its preparation method. Clin Exp Obstet Gynecol. 2013;40(3):361-6.

25. Aktop S, Çevreli B, Genç D, Serdaroğlu Kaşikçi E, Çomunoğlu Üstündağ N, Zibandeh N, et al. Effects of Ankaferd BloodStopper on dermal healing in diabetic rats. Turk J Med Sci. 2017;47(2):675-80.

26. Yurttas V, Sereflican M, Terzi EH, Ozyalvaçlı G, Kazaz H. Comparison of microporous polysaccharide hemospheres and Ankaferd Blood Stopper in a rabbit epistaxis model. Eur Arch Otorhinolaryngol. 2016;273(4):933-8.

27. Beyazit Y, Kekilli M, Haznedaroglu IC, Kayacetin E, Basaranoglu M. Ankaferd hemostat in the management of gastrointestinal hemorrhages. World J Gastroenterol. 2011;17(35):3962-70.

28. Keceli HG, Aylikci BU, Koseoglu S, Dolgun A. Evaluation of palatal donor site haemostasis and wound healing after free gingival graft surgery. J Clin Periodontol. 2015;42(6):582-9. 